\begin{tabular}{|c|c|c|}
\hline$=\frac{1}{20}$ & $\begin{array}{c}\text { PORT SAID ENGINEERING RESEARCH JOURNAL } \\
\text { Faculty of Engineering - Port Said University } \\
\text { Volume } 16 \text { No. } 1 \text { pp: } 206: 220\end{array}$ & \\
\hline
\end{tabular}

\title{
Solar Energy as an Approach for Sustainable Architecture of Residential Buildings in Egypt
}

\author{
Mostafa M. Abd El-Hafeez ${ }^{1}$, Ashraf A. EL-Mokadem ${ }^{2}$, and Dina S. Noaman ${ }^{3}$
}

\begin{abstract}
For the optimal use of solar energy (SE) in residential buildings and achieving sustainability for it , the paper is done about, energy consumption in the residential sector, renewable energy (RE), sustainability and basic design issues affecting it, and systems used in assessing the sustainability, access to the barriers that hinder RE to achieve sustainability in residential buildings. Study SE as one of the most important sources of RE to reach the residential energy producing building which led to the need to a new look of the building. Analysis and evaluation of government policies, programs, legislation and construction codes used in leader countries to exploit SE in achieving the sustainability of residential buildings, with analyzes case studies of the successful international experiences in this area and the extent of its success in achieving sustainability relying on SE, and the effect of the techniques used to shape and design of the residential building, and the effect of solar education, funding, design factors, legislation and construction codes, and government policies on the success of these experiments. Study the possibilities of Egypt in the field of RE, and the use of technology in achieving sustainability of residential buildings. With studing the current status and attempts of Egypt experiences tried to increase the contribution of SE in total energy mix in residential sector as a prerequisite to achieving sustainability of the sector, and the study result access to a strategy to encourage the use of SE in residential buildings in Egypt to achieve sustainability.
\end{abstract}

Key words: Renewable energy (RE) - Sustainability - Residential buildings - Solar energy (SE)Government policies and programs - Legislation and codes - Egypt

\section{INTRODUCTION}

Energy is crucial to the achievement of sustainable human development, and that by allowing means that contribute to the improvement of human beings living standard. As a result of wasteful patterns of consumption and production, natural resources of energy are vanishing at an unprecedented rate. In addition to the impact of this consumption, increased levels of pollution and degradation of the environmental field in general, which invited many international organizations such as the United Nations to warn of the continuation of this phenomenon, especially with the increasing numbers of population, which is paid to demand radical and central changes to develop these sources to be acceptable economically, socially and environmentally.

So , efforts recently are directed to exploit and develop RE such as solar, wind and bio-energy. Also, a lot of state

\footnotetext{
${ }^{1}$ Professor of Architecture and Urban Design Department, Faculty of Engineering, Port Said University, Egypt

2 Professor and Head of Architecture and Urban Design Department, Faculty of Engineering, Port Said University, Egypt.

${ }^{3}$ Demonstrator in Architecture and Urban Design Department, Faculty of Engineering, Port Said University, Egypt.
}

and government around the world adopted policies and new construction codes to activate the role of RE in the development of residential buildings, and the development of institutional structures capable of implementation, Nevertheless, RE use remains low. Such as advocated by the U.S. Agency for Energy that the cities could increase their economic, environmental and social efficiency by review of its energy resources and the shift to reliance on RE.

The energy sector in Egypt has witnessed significant changes in recent years reflected the pattern of production and consumption of energy, but that energy consumption in Egypt has been marked by steadily rising rates and low efficient of use. Egypt has tremendous RE sources particularly solar, wind and biomass. Egypt can participate at large rates of the basic needs from RE, particularly SE, because Egypt is located in the largest solar belt. So the transition to the use of these energies should be irreplaceable, though the exploitation of this energy in Egypt is still weak. This confirmed the need to develop long-term strategies to ensure the exploitation of SE with the development of used technology to increase the efficiency and increase production in residential buildings to convert it to energy producer buildings. 


\section{RENEWABLE ENERGY AND SUSTAINABILITY}

As a result of wasteful patterns of consumption and production, traditional energy crisis occurs globally from 2010 to 2020 [']. Residential building sector is the most energy-consumer sector globally after the industrial and transport sectors. RE technologies can drastically reduce energy consumption to enable this sector to become energy neutral or to change into plus energy producers.

RE global contribution (not counting hydropower) is still weak [2], despite the ability to contribute socially, economically, environmentally and thus achieve sustainability as shown in figure 1 .

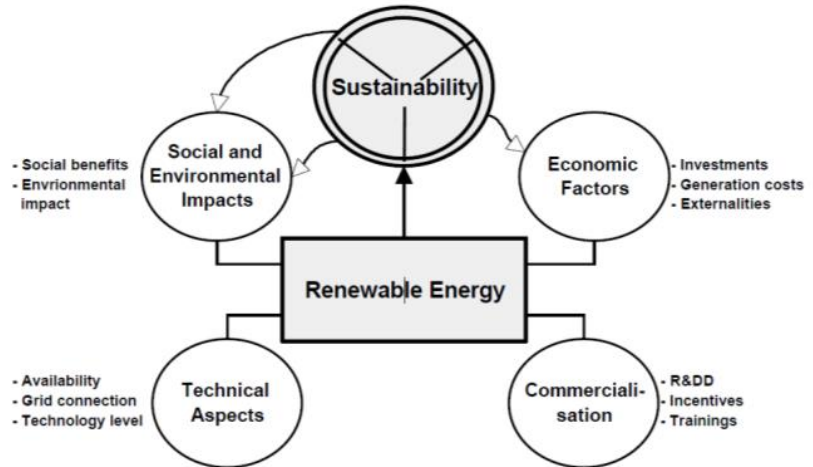

Figure 1: the major considerations for developing RE technologies to achieve Sustainability [3].

Architecture and design moved

towards sustainability as a way to solve the environmental problem, especially the energy problem. Through the study of sustainability assessment systems, found that the energy fields are more attributed to the achievement of sustainability (such as LEED assessment system where energy fields have $\% 27$ attribution as shown in figure 2 ).

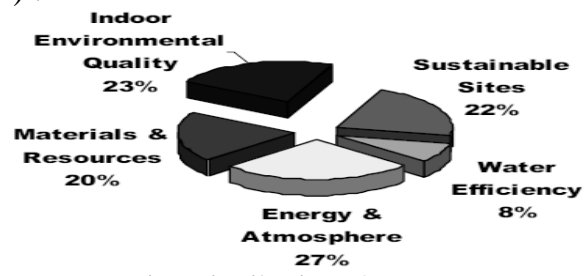

Figure 2: LEED Point Distribution [3].

RE diffusion and contribution in achieving sustainability is slow due to lack of incentive policies and programs, lack of awareness, lack of funding, and lack of legislation and laws governing its use. Rigorous methods are needed to accelerate the development and utilization of RE, and to increase its contribution to the current energy supply mixes to achieve sustainability, especially in the field of residential buildings architecture which represents the main way to spread sustainability.

Accordingly, provide the architects and planners with sustainable design approaches are necessary. These sustainable design approaches include reduce building material wastage, increase the use of recycled waste, conserve water, utilize natural and RE on site, such as solar, biomass, and wind energy.

Through the study of RE sources, SE is the most renewable clean energy that convenient to the residential sector, because of its availability and multiplicity of its uses that suitable for different housings.

\section{SOLAR ENERGY TO REACH THE SUSTAINABLE ENERGY- PRODUCING RESIDENTIAL BUILDINGS}

SE reaches the Earth in large unused quantities. It isn't a new approach but it is found since building houses existed. So modern homes must be energy self-sufficient from SE.

There are many SE conversion systems suitable for use in residential buildings (Solar thermal systems, and PV systems). The use of these systems is no longer a future, but a reality which affect the building and similarly the building design affect on the successful use of these systems.

\subsection{Aspects Affecting on the Performance and Design of Solar Energy Systems}

Once the availability of appropriate environmental factors, the design become the main issue affecting the performance of the solar system.

\subsubsection{Orientation}

Normally true south is the best and most frequent choice[4].

\subsubsection{Tilt Angle ( $\beta$ )}

It is measure between the solar modules and the ground. For PV collectors see table 1 and For thermal solar collectors see table 2 .

Table 1 : recommended title angles for a fixed PV system [5].

\begin{tabular}{|c|c|}
\hline Site latitude in degrees & Fixed tilt angle \\
\hline $0^{\circ}$ to $15^{\circ}$ & $15^{\circ}$ \\
\hline $15^{\circ}$ to $25^{\circ}$ & Same as latitude \\
\hline $25^{\circ}$ to $30^{\circ}$ & latitude $+5^{\circ}$ \\
\hline $30^{\circ}$ to $35^{\circ}$ & latitude $+10^{\circ}$ \\
\hline $35^{\circ}$ to $40^{\circ}$ & latitude $+15^{\circ}$ \\
\hline $40^{\circ}+$ & latitude $+20^{\circ}$ \\
\hline
\end{tabular}

Table 2 : recommended title angles for a fixed thermal solar system [4].

\begin{tabular}{|l|c|}
\hline \multicolumn{1}{|c|}{ Season of use } & Fixed tilt angle \\
\hline For all year domestic hot water (DHW) & Same as latitude \\
\hline For all year DHW and winter space heating & latitude $+10^{\circ}$ to $15^{\circ}$ \\
\hline For winter only space heating & latitude $+10^{\circ}$ to $15^{\circ}$ \\
\hline $\begin{array}{l}\text { For all year DHW, winter space heating, } \\
\text { and summer cooling }\end{array}$ & Same as latitude \\
\hline For summer space cooling & latitude $-10^{\circ}$ to $15^{\circ}$ \\
\hline $\begin{array}{l}\text { For summer only space cooling and all } \\
\text { year DHW }\end{array}$ & latitude $-10^{\circ}$ to $15^{\circ}$ \\
\hline
\end{tabular}

\subsubsection{Shading}

The collectors must be kept out of the shade, especially between 9 a.m. and 3 p.m., when most of the 
useful energy collection occurs [4]. PV modules are very sensitive to shading unlike a thermal solar panel which can tolerate some shading [6].

\subsubsection{Location of equipment}

Placement optimizes conditions by having short runs of delivery.

\subsubsection{Maintenance}

Systems should be designed for minimum maintenance. For thermal solar collectors a diligent maintenance practice is recommended. For PV System every maintenance six months [4].

\subsection{Solar Energy Technologies Options Which Appropriate to Apply in Residential Buildings}

Solar systems capture incident solar radiation energy and either convert it to heat (thermal energy) or directly to electricity (PV) [7] or to heat and electricity together.

\subsubsection{Solar thermal systems}

Thermal Solar systems use the heat collected from solar energy to heat a fluid, either air or liquid by passive or active systems. This fluid then is used- directly or indirectly- to heating or cooling or lighting or cooking for household use. It are the most suitable solar systems for residential buildings, because it have several applications such as Solar Water Heating (figure 3), Solar Heating of Swimming Pools (figure 4), Space Heating (figure 5), Solar cooling systems, Hybrid-Solar Lighting (HSL) Technology (figure 6), and Solar Cooking (figure 7). With the necessity of taking into account the quality of design and sizing of system components. Also the combination of more than one use (DHW and Swimming Pool Heating Systems- Space and Water Heating Systems (figure 8)- Solar Heating and Cooling System) is an efficient way to achieve many benefits.
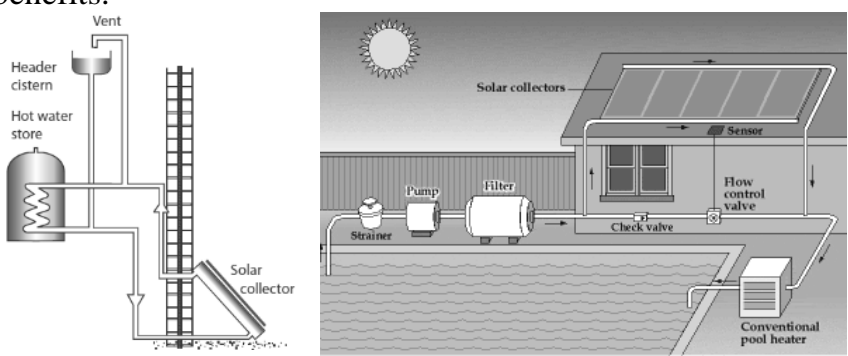

Figure 3: A thermosiphon Figure 4: a solar pool heating system SWH system [8].
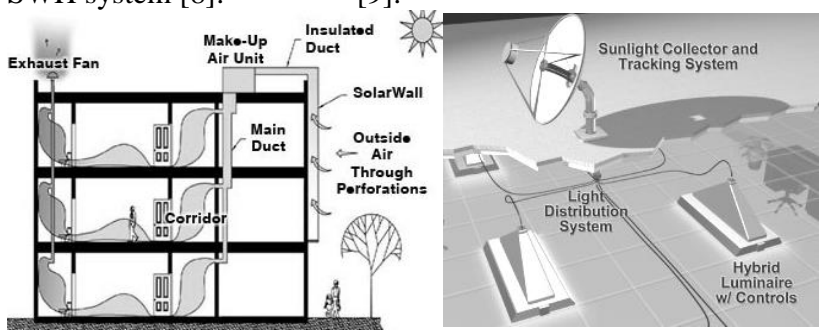

Figure 5: SolarWall system in residential buildings [10].
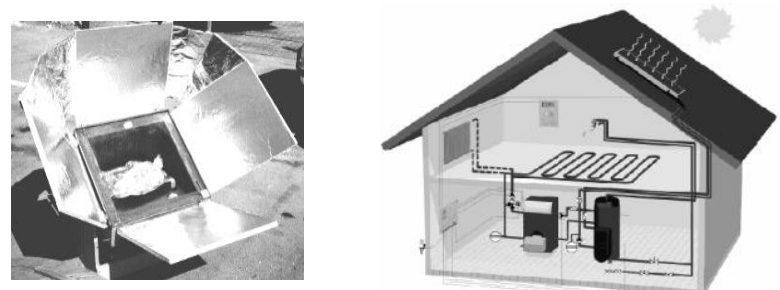

Figure 7: Solar Cooker [12]. Figure 8: Space and Water Heating Systems [12].

\subsubsection{Photovoltaic (PV) Systems}

Many types of PV systems give the field for architects to choose appropriate system for the residential buildings in terms of area, shape, or the availability of the electricity grid (figure 9 and figure 10). With also the necessity of taking into account the quality of design and sizing of system components to achieve economic benefits.

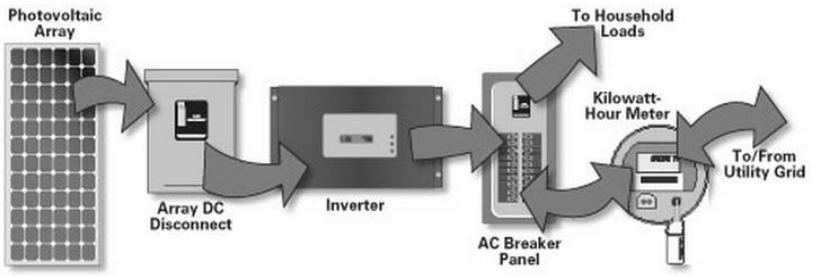

Figure 9: grid intertie PV system components [13].

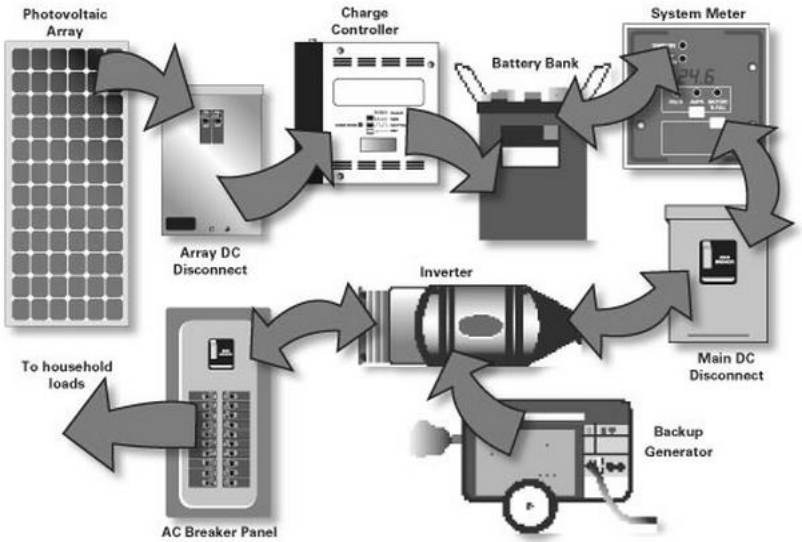

Figure 10: off grid PV system components [13].

In urban environments there is usually a limited amount of space available for mounting PV modules. In these situations there are some solutions: crystalline modules are more efficient, so less surface area is required and thin film modules can be integrated into buildings, so no extra land space is required [14]. Due to the use of the building and its components to generate energy (BIPV), PV systems are affect a significant impact on the architectural aspects of the building. BIPV is a new look to the building, replacing traditional building materials such as roofs, facade, and windows with building materials that produce energy. So it is better to use it in case of new construction, or retrofit to existing buildings.

\subsubsection{Combined solar PV and thermal collectors}

Combination of solar thermal systems and PV makes the system more efficient and save spaces, see figure 11. The collector looks just like a solar thermal 
collector but the back plate is replaced with the PV surface that generates electricity. There is an actively cooling for PV collectors in a PVT collector [15].

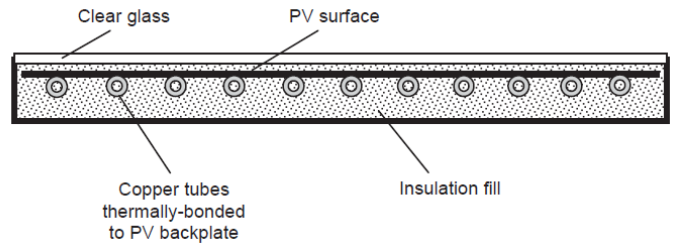

Figure 11: Cross-section of a Combined solar PV and thermal collector [15].

\subsection{Solar Collectors Mounting Options Which Appropriate To Apply in Residential Buildings}

There have been many ways to mounting the solar collector in proportion with the building and available space with appropriate conditions. It can be mounted as following:

- Adjacent to the building:

- Ground mounting: it can be fixed racks (figure 12), or tracking racks

- Separate structure mounting (figure 13): to provide a place for solar system equipments.

- Additions to the building:

- Rack installations: : it can be anchored (figure 14), or ballast (figure 15), or quick deployment ballast bin (figure 16). It uses to place panels on flat roofs.

- Flush Mounting (figure 17)): It uses to place panels on pitch roofs which have right orientation.

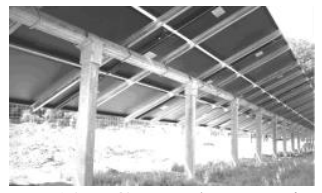

Figure 12: Ground mounting (Fixed racks) [16].

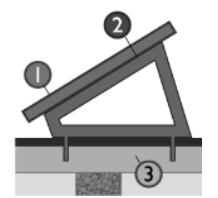

Figure 14: anchored mounting method:(1) Solar panels , (2) a frame, (3) roof structure [18].

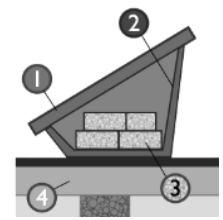

Figure 16: ballast mounting plastic molded bin,(3) concrete a frame, (3) roof structure weight, (4) roof structure [18].

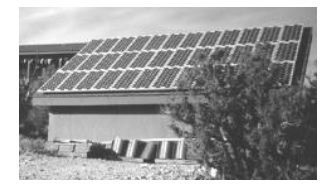

Figure 13: Separate structure mounting PV [17].

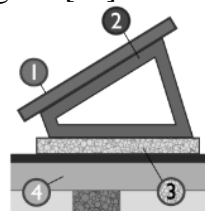

Figure 15: ballast mounting method:(1) Solar panels , (2) a frame,(3) concrete weight, (4) roof structure [18].

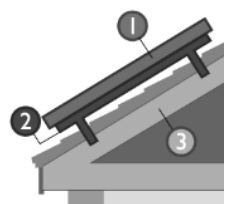

Figure 17: flush mounting [18].

- Integration with the building roof (figure 18) or faced (figure 19) is the best ways to mounting the system because it replaces the building materials and produce energy in addition to other functions when integrated with the building elements such as clerestory windows (figure 20), Stair room on the building roof (figure 21), awnings and canopies (figure 22), and sky light (figure 23).

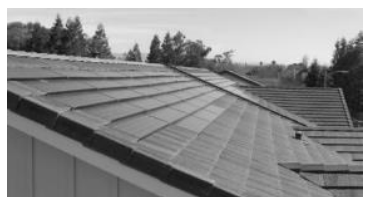

Figure 18: PV shingles

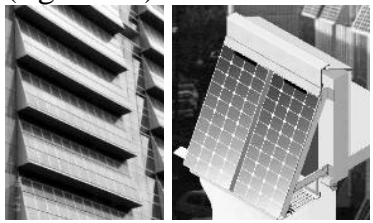

Figure 19: Integrated PV on integrated into the roof of house saw-tooth faced design [9]. in San Diego, California [19].

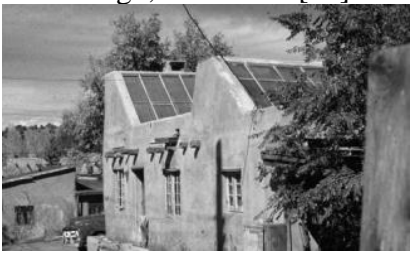

Figure 20: A north facing rooftop clerestory windows with solar equipment on south facing [17].

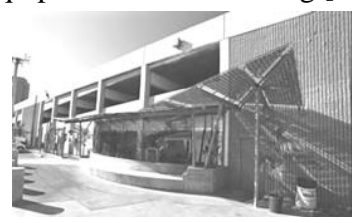

Figure 22: BIPV shading for building entrance [20].

\subsection{Change in the Form and Design of Residential Buildings Which Use Solar Energy Technologies (A New Look of the Building)}

Using solar systems changes the building shape and design, and thus creates new architectural trends lead to single purpose of residential sustainable buildings which achieve partial or total energy sufficiency from SE. Some of these architectural trends are:

- Eco Houses (figure 24): its rules are [22]:

- Doesn't depend on any traditional means of heating, but replace them with solar energy only.

- Depends on the construction of wood and glass.

- Characterized by the multi-colors of external interfaces.

- The interior is characterized by open rooms to each other.

- Zero Energy Homes (figure 25): A good ZEH should first encourage energy efficiency, and then use RE sources available on site. It produces as much energy from renewable energy as it uses [19].

- Prefabricated Home Design (figure 26): it are built entirely in a factory and then transported to building site and installed. It can be designed for 
energy efficiency and use renewable energy systems [2].

- Ultra-Efficient Home Design (figure 27): include the following design features [2]:

- Passive solar heating and cooling

- Energy-efficient construction

- Energy-efficient appliances and lighting

- Solar water heating system

- Small solar electric system

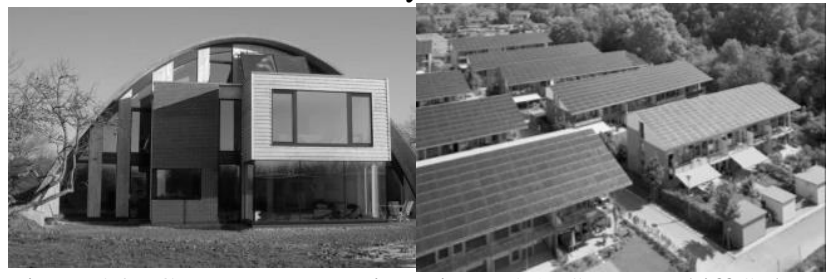

Figure 24: Crossway House is Figure 25: Sonnenschiff Solar an Eco home in the UK [23]. City in Freiburg, Germany [23].

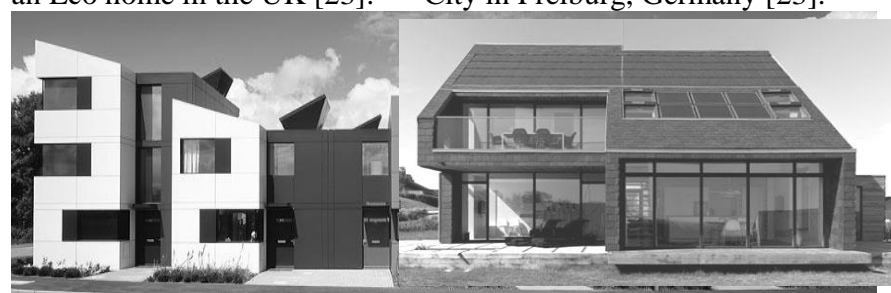

Figure 26: Oxley Park houses Figure 27: Modern Ultra (Panelized Prefabricated Efficient Home located in Homes) in UK [23]. Denmark [23]

\section{SOLAR POLICIES, LEGISLATION AND CODES TO EXPLOIT SOLAR ENERGY IN RESIDENTIAL BUILDINGS}

Policies and programs to encourage the use of SE systems is the principal means to achieve the optimal spread of these systems on the residential level. These policies are:

- Economic policies and programs motivating to the use of solar systems through financial support for these systems at all levels (Individuals pay attention to the economic aspect). USA, especially California is considered the most successful countries in this area, because of its provisions of various and successful policies such as personal tax credit, property tax exclusion for solar systems, and California solar initiative. Also some incentive policies -still at its beginning- appeared in arab countries like Abu Dhabi, and Lebanon.

- Policies to increase the role of solar education in achieving the sustainability of the residential communities. Solar education has an essential role in the individual acceptance of the idea of SE as first stage and even reached for how to deal with it professionally. This will be undertaken through the availability of information and knowledge, availability of training and its levels, availability of awareness, and availability of information on the Internet.
- Policies to review environmental financing sources (local and International sources) and deal with these sources to contribute to sustainabable achievement in residential building depending on solar systems.

Legislations and codes are the essential organization key for the use of solar systems in residential buildings. Regulating the use of solar systems is leading to achieve ease of systems use and thus promote its use. To regulate the use of solar systems in codes, it need to:

- Add energy rating in codes to reduce energy consumption and thus achieve sustainability and more efficiency for solar systems economically. A Home Energy Rating (HERS) is an energy rating in USA. Each 1-point decrease in the HERS Index corresponds to a $1 \%$ reduction in energy consumption compared to the HERS Reference Home [24] (see figure 28).

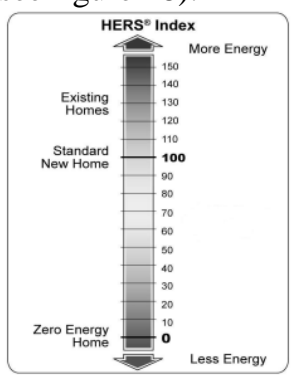

Figure 28: The HERS Index [24]

- Legislation regulating sun access to the location through determine the height of the buildings and planning the site such as 'solar envelope' rule (a 3dimensional surface, on a given site, that does not obstruct more than $\mathrm{n}$ hours of sun onto adjacent sites), as shown in figure 29.

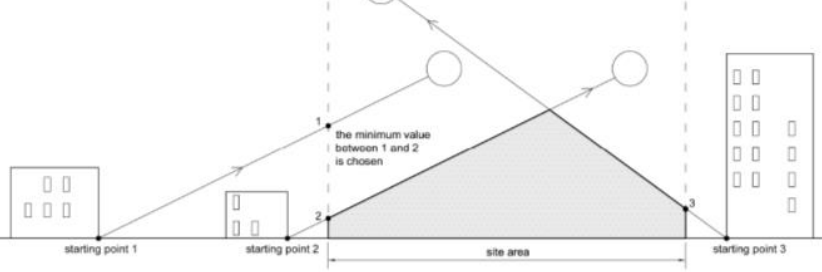

Figure 29: The conceptual construction of the script for calculating solar envelope [25]

- Legislation to ensure the solar rights of users in residential buildings to regulate the relationship among the population. California is considered the most successful city in setting these legislations in codes.

- Codes contain requirements and conditions for the installation of solar systems with the observance to mandate these requirements to comply with the Code. California is the most successful government in setting requirements for the installation of PV systems and solar thermal systems (With the knowledge of proximity between the Egypt and California in the availability of energy sources, which falls on the same latitude). 
- Some of PV system conditions to comply with California codes requirements are:

- Access/Pathways: For single and two-unit residential dwellings, Modules should be located in a manner that provides two $90 \mathrm{~cm}$ wide access pathways from the eave to the ridge. For residential housing comprised of three or more units, There should be a minimum $180 \mathrm{~cm}$ wide clear perimeter around the edges of the roof [26].

- General height requirements: For pitched roof see figure 30 and for flat roof see figure 31 .

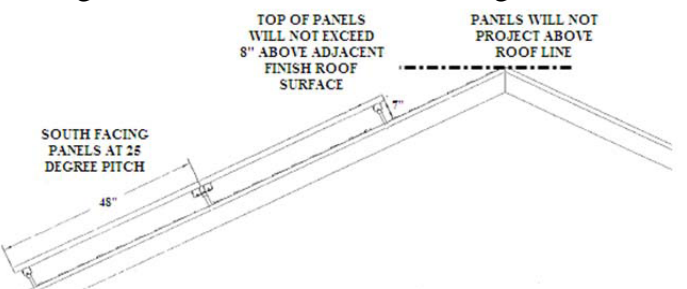

Figure 30: General height requirements for pitched roof [27]

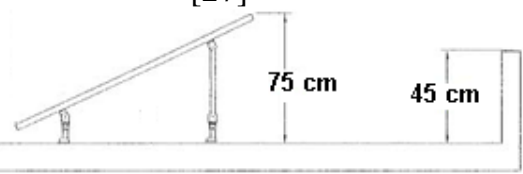

Figure 31: General height requirements for flat roof [27] - For located in yards requirements, see figure 32. It aren't permitted in a front yard, except for greenhouses that are integrated into the principal structure. In a side yard, no closer than $90 \mathrm{~cm}$ from the side property line; and in a rear yard, no closer than $450 \mathrm{~cm}$ from the rear property line and $150 \mathrm{~cm}$ from any principal or accessory structure [28].

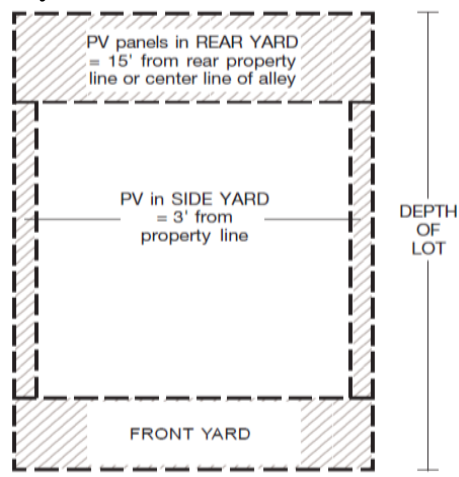

Figure 32: Solar module setback requirements [28].

- Mechanical installation requirements: by selecting a suitable location, and installing securely of the roof mount.

-Electrical installation requirements: by grounding the solar system.

- Some of Solar heating systems conditions to comply with California codes requirements are:

- It is mandatory for pools or spas in residential buildings in the case of using electric heaters to get $60 \%$ or more of their annual heating from site solar energy [29].
- If a pool does not currently use SWH, piping must be installed to accommodate any future installation [29].

- At least $60 \%$ of the energy needed for service water heating from site solar energy in the case of 50 gallons or less water heating systems [29].

- At least $25 \%$ of the energy needed for service water heating from site solar energy in the case of more than 50 gallons water heating systems [29].

- Mandatory pipe insulation (1 inch of R-4 insulation for 2 inches pipes and $11 / 2$ inch insulation for pipes greater than 2 inches), and storage tank insulation (R-12 or internally insulated with R-16) [29].

\section{INTERNATIONAL PRACTICAL STUDIES TO MAXIMIZING SOLAR ENERGY USE IN RESIDENTIAL BUILDINGS}

The paper presents number of different residential experiences, which increased the contribution of RE particularly SE in total energy mix to achieve sustainability. Access through these experiences to a number of results that emphasizes the need to go to SE in residential buildings as an effective approach for sustainable architecture. In selecting examples for analysis the limits used are : include different solar systems, site locate in south U.S.A. because it is similar to Egypt in terms of the availability of the sun (The same latitude), diversity in time limit 20 and 21 century examples (designed in 1995 to 2009), and Diversity in following or not following the code, legislation, design elements of solar systems, policies (incentives), solar education, and environmental financing. Methodology of analysis includes: the project defining and concept, Annual Energy consumption, Energy conservation, aspects affecting on the performance and design of SE systems, Annual Pollution avoided from using SE systems, The achievement extent of sustainability by using LEED rating system, Policies and Environmental financing sources used to reduce the cost of solar systems, available solar energy education, and The application extent of legislation and codes.

The list of assessed projects includes:

- EX.1: Bircher Home, WI, USA ,1999 (figure 33)

- EX.2 : Los Vecinos Affordable Rental Apartments, CA, USA,2009 (figure 34)

- EX.3:Heavenly Retreat Home,NM,USA,2002(figure 35)

- EX.4 :Berkeley House, CA, USA,1995 (figure 36)

- EX.5: Florida Solar Cracker House, FL, USA, 1998 (figure 37)

- EX.6: George Beeler Home,CA,USA,2005(figure 38) 


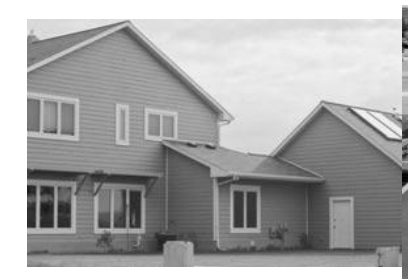

Figure 33: The Bircher Home [30].

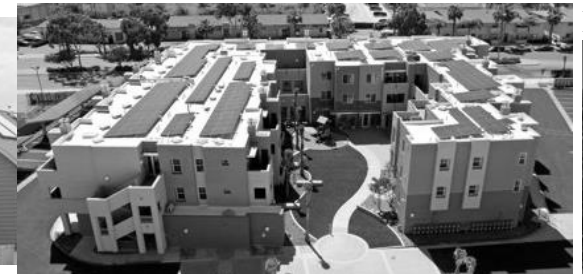

Figure 34: Los Vecinos Affordable Rental Apartments [31].
Retreat Home [32].

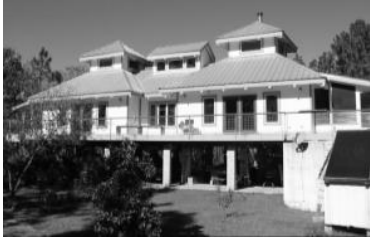

Figure 37: The Florida Solar Cracker House [ r 4$]$. [r3].

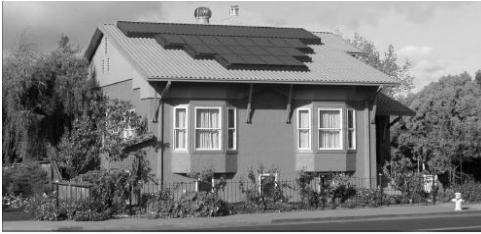

Figure 38: The Home office of George Beeler [r5].

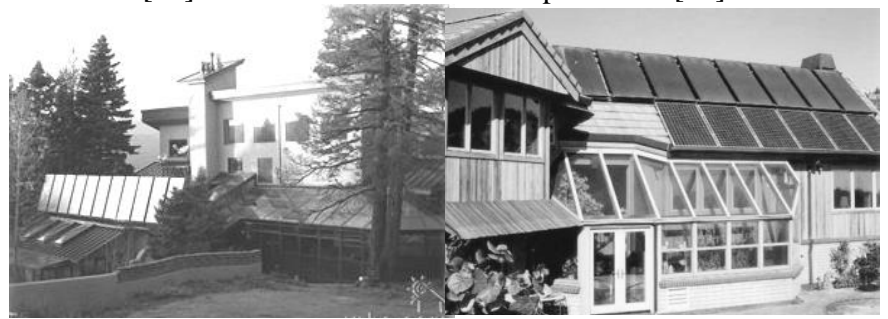

Figure 35: The Heavenly Figure 36: The Berkeley House

Table 3 : Effects by and on solar systems for previous International practical studies

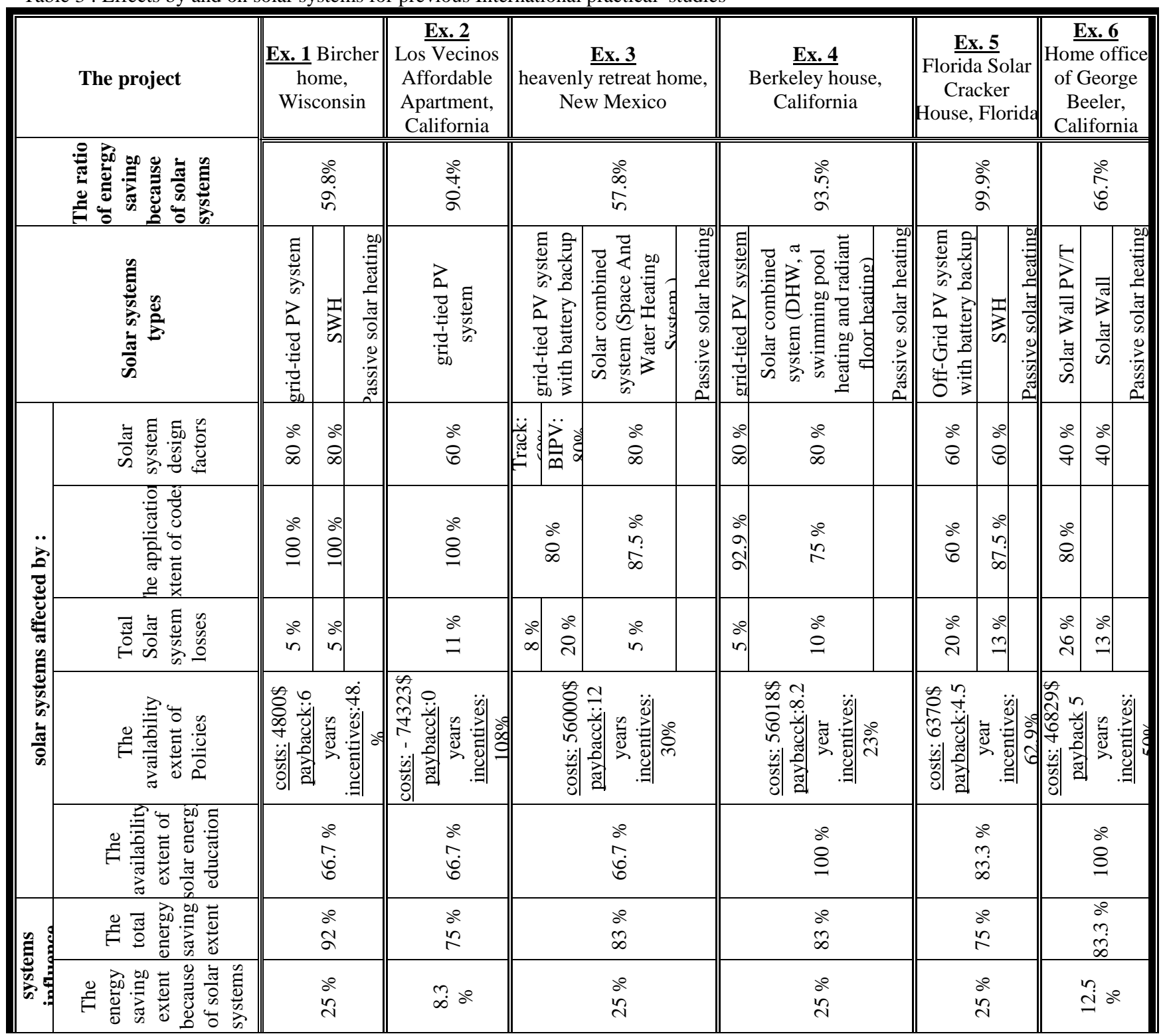




\begin{tabular}{|c|c|c|c|c|c|c|}
\hline Е & $\begin{array}{l}D^{\circ} \\
\dot{n} \\
i n\end{array}$ & $\begin{array}{l}0^{\circ} \\
0 \\
\ddot{\infty} \\
\infty\end{array}$ & $\begin{array}{l}\stackrel{0}{0} \\
\text { q }\end{array}$ & $\begin{array}{l}\stackrel{2}{n} \\
\check{n}\end{array}$ & $\begin{array}{l}2 \\
\text { aे }\end{array}$ & $\frac{\infty}{2}$ \\
\hline 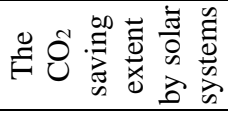 & 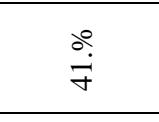 & ڤ̊ & $\begin{array}{l}b^{\circ} \\
q\end{array}$ & $\begin{array}{l}\stackrel{0}{\text { i }} \\
\infty\end{array}$ & बें & $\begin{array}{l}\infty \\
\dot{i} \\
\dot{n}\end{array}$ \\
\hline 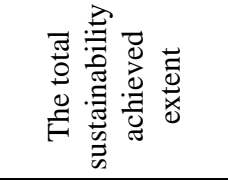 & 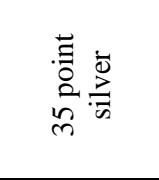 & 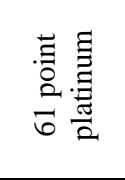 & 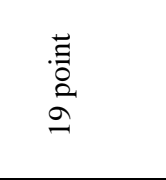 & 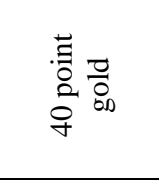 & 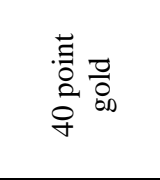 & 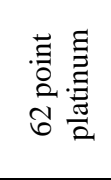 \\
\hline 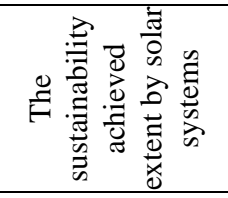 & 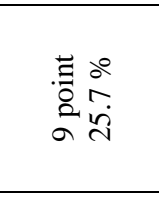 & 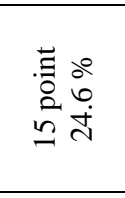 & 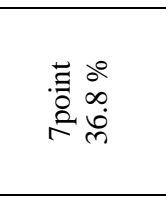 & 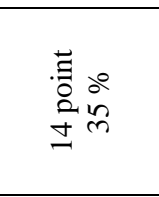 & 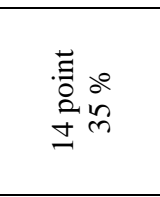 & 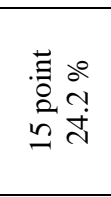 \\
\hline 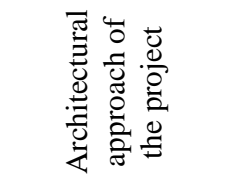 & 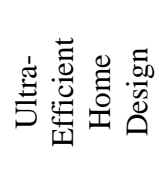 & 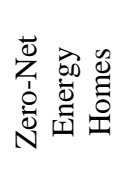 & 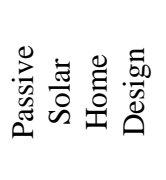 & 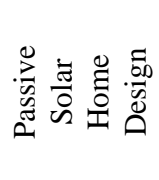 & 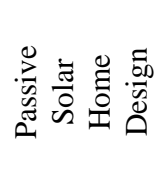 & 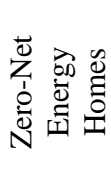 \\
\hline
\end{tabular}

The analysis of these projects shows the following results:

- Relationship between the design efficiency and the working efficiency of solar systems:

- From figure 39, The more the design efficiency increased (by increase following solar PV systems design factors and codes), the more the working efficiency increased (by decrease total losses for solar PV systems).

- From figure 40, The more the design efficiency increased (by increase following solar thermal systems design factors and codes), the more the working efficiency increased (by decrease total losses for solar thermal systems).

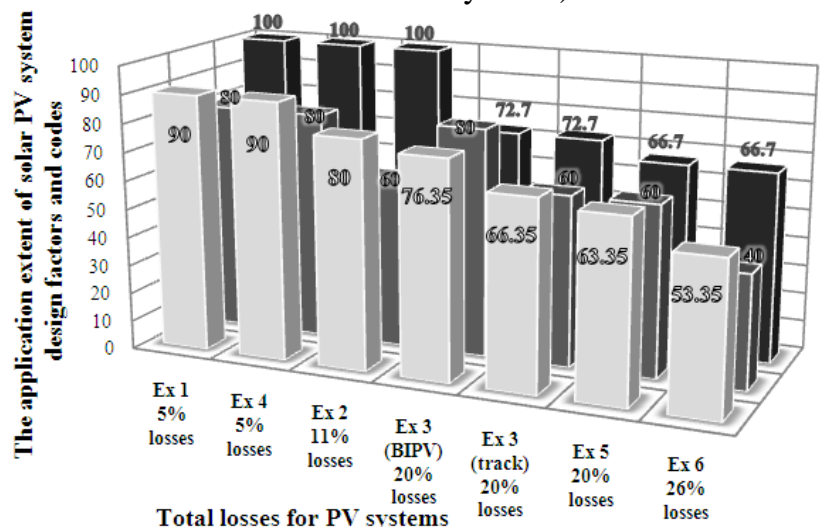

Total losses for PV systems losses losses losses

whe application extent of solar PV system design factors and codes

- The application extent of solar PV system design factors

- The application extent of solar PV system codes

Figure 39 : Relationship between the design efficiency and the

working efficiency of solar PV systems [researcher].

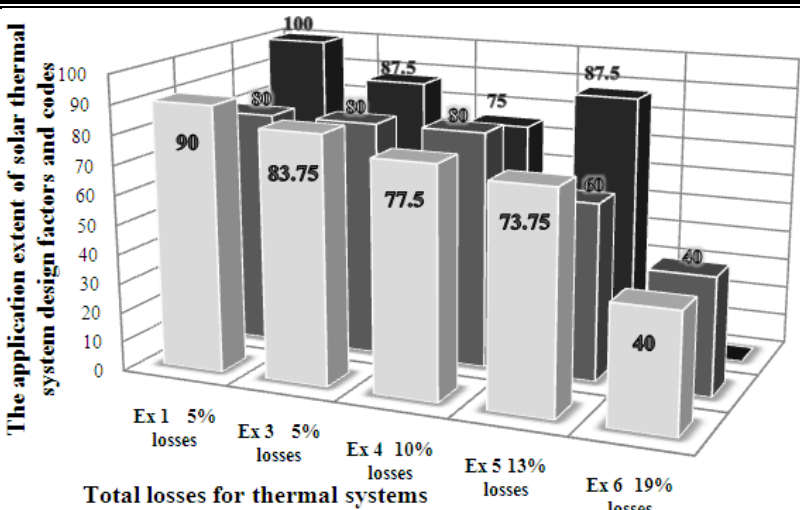

$\begin{array}{cc}\text { Total losses for thermal systems } & \text { losses } \\ \mathrm{Ex} 6119 \% \\ \text { losses }\end{array}$

"The application extent of solar thermal system design factors and codes - The application extent of solar thermal system design factors

- The application extent of solar thermal system codes

Figure 40 : Relationship between the design efficiency and the working efficiency of solar solar thermal systems [researcher].

- Relationship between the availability extent of policies (incentives) \& solar education and the use extent of solar system: From figure 41, Policies (incentives) encourage the use of solar systems (by increase the ratio of energy saving by solar systems) until the ratio of energy saving by solar systems become $90 \%$. When exceed this ratio the owners don't care about incentives but have enough solar education to achieve $90-100 \%$ ratio of energy saving by solar systems. 


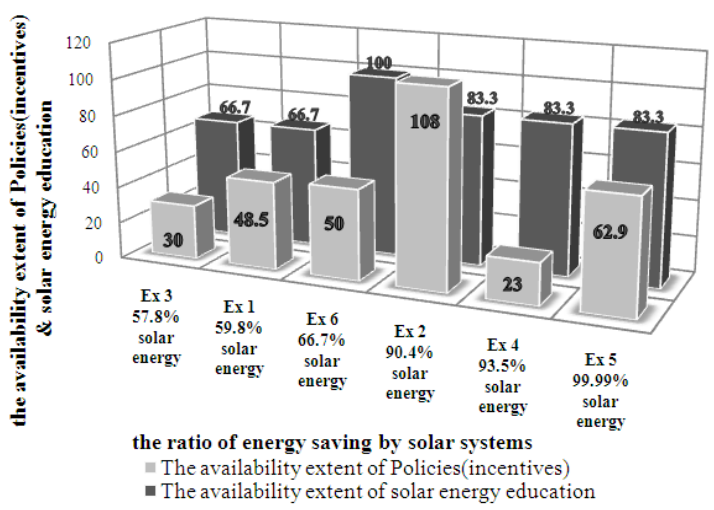

Figure 41 : Relationship between the availability extent of policies \& solar education, and the use extent of solar system [researcher].

- Relationship between the use extent of solar system and the extent of total energy saving: From figure 42 , When increase the use of solar system until become $60 \%$, this increase the total energy saving extent. When exceed this ratio, the total energy saving extent doesn't increase. So It is better to check out other conservation procedures than solar systems.

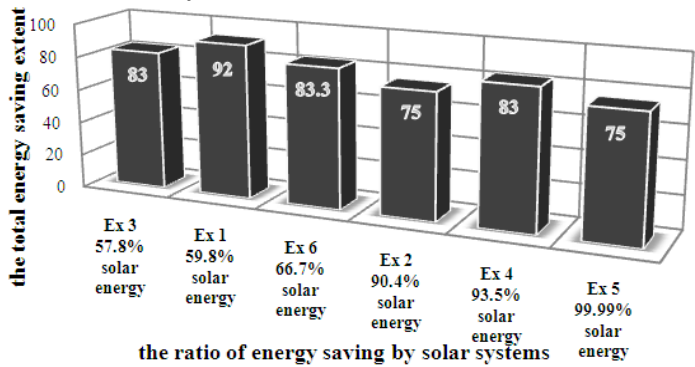

Figure 42 : Relationship between the use extent of solar system and the extent of total energy saving [researcher].

- Relationship between the use extent of solar system and the extent of total $\mathrm{CO}_{2}$ saving: From figure 43 , When increase the use of solar system (by increase the ratio of energy saving by solar systems), this increase the total $\mathrm{CO}_{2}$ saving extent.

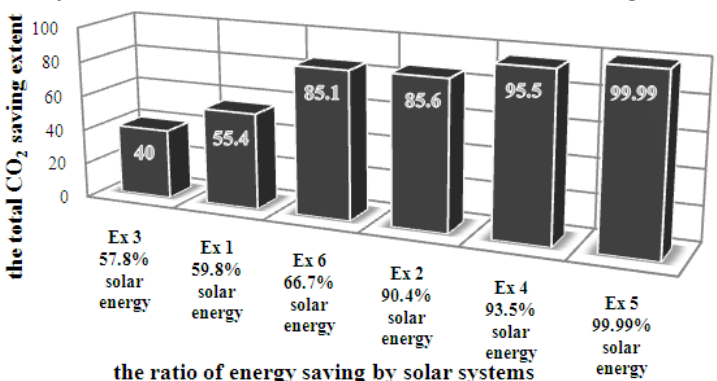

Figure 43 : Relationship between the use extent of solar system and the extent of total $\mathrm{CO}_{2}$ saving [researcher].

- Relationship between the use extent of solar system and the extent of sustainability achieved: From figure 44, When increase the use of solar system (by increase the ratio of energy saving by solar systems) until become $67 \%$, this increase the total sustainability achieved extent. When exceed this ratio, the sustainability achieved extent doesn't increase. So It is better to check out other procedures than solar systems to become more sustainable.

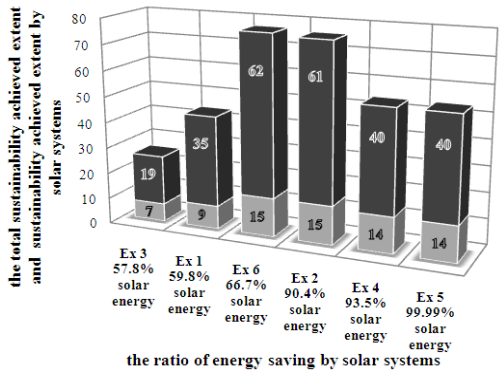

Figure 44 : Relationship between the use extent of solar system and the extent of sustainability achieved [researcher].

From previous results, it can be concluded that [researcher]:

- Solar systems and its efficiency are affected by building design, codes and legislation follow, and solar systems design factors follow.

- Solar systems and its spread in residential buildings are affected by the availability of incentive policies and programs, and solar education.

- Solar systems influence on total energy saving extent, total $\mathrm{CO}_{2}$ saving extent and sustainability achieved extent. So, the ability of the transformation to use SE in residential buildings to achieve energy conservation, avoide $\mathrm{CO}_{2}$ emissions, and achieve sustainability.

- Solar systems influence on form \& design of the building by appear several architectural approaches. Solar systems affected by form \& design of the building by follow the building to solar system efficiency design factors.

\section{RENEWABLE ENERGY SITUATION REVIEW IN EGYPT}

\subsection{National Energy Outlook}

Scientific study expected Egypt's transition to importer country of oil by the year 2017[36]. Nevertheless, The plan of Ministry of Electricity and Energy (MOEE) hasn't potential interest in deploying the RE for power generation[37].

The residential sector can be considered the major consumer of energy in Egypt after the industrial sector (figure 45) due to urban expansion and the widespread use of domestic appliances [38]

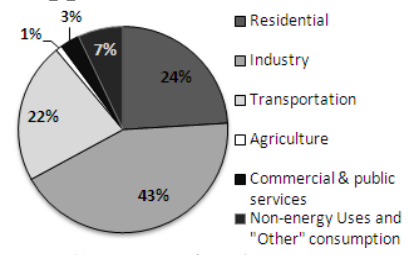

Figure 45: Energy Consumption by sector, Egypt, 2005 [38].

\subsection{National RE sources}


For Wind energy, a wind atlas of Suez Gulf area was issued in 1996. Wind Farms in Egypt are currently working (the beginning of 2011) with 550MW installed capacity like Zafarana Wind Farm[37].

For Thermal solar energy, maadi, Cairo in 1914, The first station of its kind in the world. The solar atlas was issued in 1991. In 2009, Kuraymat Solar Thermal Power Plant (150 MW) is operated [36]. About 350 thousand sets of SWH was installed in Egypt until 2009 ( $36 \%$ for new cities, $12 \%$ for residential communities and $4 \%$ individuals and villas) [39].

For Electric solar energy, its total capacity in Egypt ranges from 4 to $4.5 \mathrm{MW}$, for the different sectors. The estimated total installed power in the rural electrification and solar lighting pole sector is $750 \mathrm{~kW}_{\mathrm{P}}$ (the most applying sector) [37].

For Biomass, The total amount of biomass is of the order of 60 million ton/y, but significant quantities of it used for other purposes instead of energy[37].

\subsection{Current Status for Enhance The Use of RE, Particularly SE Systems, in The Egyptian Residential Sector}

RE technologies haven't reported a valuable level of required sophistication in Egypt because of lack of incentive policies from the government, lack of awareness, difficult situation of financial constraints, and absence of SE standards.

\subsubsection{Egypt current policies on RE particularly SE systems}

The energy policy of Egypt focuses on the promotion of RE but with large capacity. Egypt also established specialized institutions such as the New and Renewable Energy Authority (NREA) [39]. But incentive policies haven't been developed to encourage individuals, In addition to the absence of the possibility of a connection of small producers to the network.

For SE systems local manufacturing, $\underline{\text { SWH system has }}$ been manufactured in Egypt since the early eighties by manufacturers such as Arab Organization for Industrialization and Egyptian American Group for Investment. PV production has been begun in 2007 by Arab World Optics company[37].

\subsubsection{Egypt current status of solar education}

Some training programs are available by NREA. Also ahram newspaper has done a weekly supplement under the name of our environment is our life to provide public awareness. But information, knowledge, public awareness, training levels, and modern computing technology haven't been developed.

\subsubsection{Egypt current status of financial instrument to support SE systems}

In Egypt, most of funds were made available via international programs and foreign donors. local and common funding is very weak, which make it difficult to use solar systems because of its high prices.

\subsubsection{Egypt current status of legislations and building codes that organize the use of SE in residential buildings}

legislations concerned with only buildings energy efficiency and domestic machines (the labels card), and issued codes for that.

On behalf of The Egyptian Green Building Council, the Housing and Building National Research Center issued the Green Pyramid Rating System in May 2010. It provides definitive criteria by which the environmental credentials of buildings can be evaluated, and the buildings themselves can be rated. Additionally, the system should assist building designers, constructors and developers to make reasoned choices based upon the environmental impact of their decisions [40].

Also Law No. 106 of 1976 in extended and regulates the construction amended by the Act 101 for the year 1996 addresses the maximum heights of residential buildings not exceed 1.5 the road width with $36 \mathrm{~m}$ maximum. From figures 46 and figures 47 , by implementing the law the building height exceeds the solar envelope. So this law doesn't take into account the sunlight access to the site and neighboring sites.

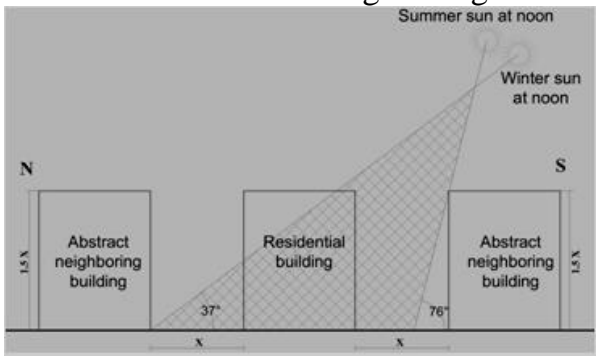

Figure 46 : north and south solar envelope in residential building in Egypt [researcher].

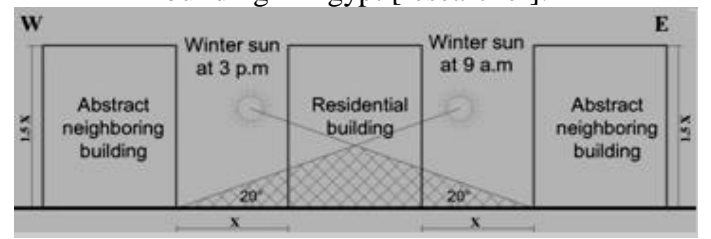

Figure 47 : west and east solar envelope in residential building in Egypt [researcher].

\subsection{Practical Residential Experiences in Egypt, Which Increase The Contribution of Solar Energy in Total Energy Mix to Achieve Sustainability}

This part presents different Egyptian residential experiences to evaluate the current situation of solar technologies application in Egypt and to evaluate the impact of lack of incentive policies, lack of awareness, difficult situation of financial constraints, and absence of SE standards on the success of solar systems. In selecting examples for analysis the limits used are : include different solar systems, Diversity of residential buildings types (apartment building - separate housing), diversity in time limit 20 and 21 century examples (designed in 1992 to 2009), and Diversity of location 
(downtown area - remote area). The methodology used in analyzing the examples is the same way as previous practical residential experiences.

The list of assessed projects includes:

- EX 7: Low-Cost Solar Energy Housing, Port Fuad, Egypt, 1992 (figures 48).

- EX 8: Remote Om-Alsagher Village Electrification by PV in Gara Oasis, Siwa Oasis, Egypt, 2010 (figures 49).
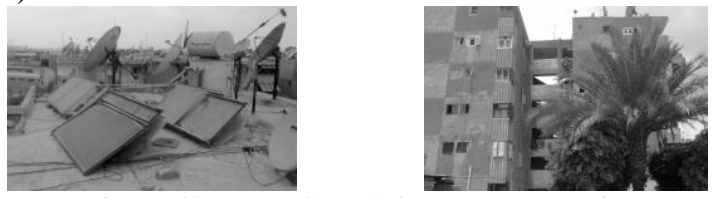

Figure 48: Low-Cost Solar Energy Housing .
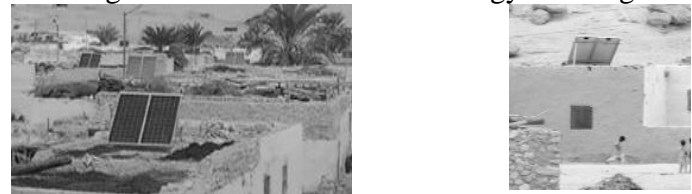

Figure 49: Remote Om-Alsagher Village [38].

Table 3 : Effects by and on solar systems for previous Egyptian practical studies

\begin{tabular}{|c|c|c|}
\hline The project & $\begin{array}{l}\text { Ex. } 7 \text { Low- } \\
\text { Cost SE } \\
\text { housing }\end{array}$ & $\begin{array}{c}\text { Ex. 8 Remote Om- } \\
\text { Alsagher village } \\
\text { electrification in by } \\
\text { PV systems }\end{array}$ \\
\hline 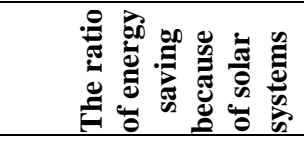 & $\begin{array}{l}\stackrel{0}{0} \\
\infty \\
\stackrel{0}{0}\end{array}$ & $\begin{array}{l}00 \\
n \\
2\end{array}$ \\
\hline 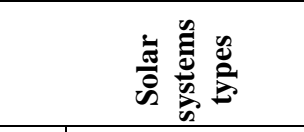 & $\sum_{n}^{T}$ & 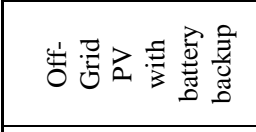 \\
\hline 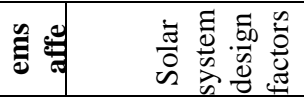 & $8 \circ$ & $\infty \infty^{\circ}$ \\
\hline
\end{tabular}

The analysis of these projects shows the following results [researcher]:

- The radical difference in dealing with SE from 1992 to 2010 where institutions dealing with SE are found such as NREA.

- The availability of some few means of solar education recently.

- The application of design factors of solar system and requirements of global codes for the design and installation of solar systems is still weak, which leads to poor system efficiency and increase losses.

- The application of energy efficiency in residential buildings is still weak.

- The application of sustainability in residential buildings is still weak.

- SWH system achieves $\mathrm{CO}_{2}$ emissions avoided more than PV system.

- Recently, the availability of interest in the new architectural trends which encourage the use of SE.

- Although the integration of solar system addition during the design process in EX 7, but the experiment didn't succeed. Despite the addition of the solar

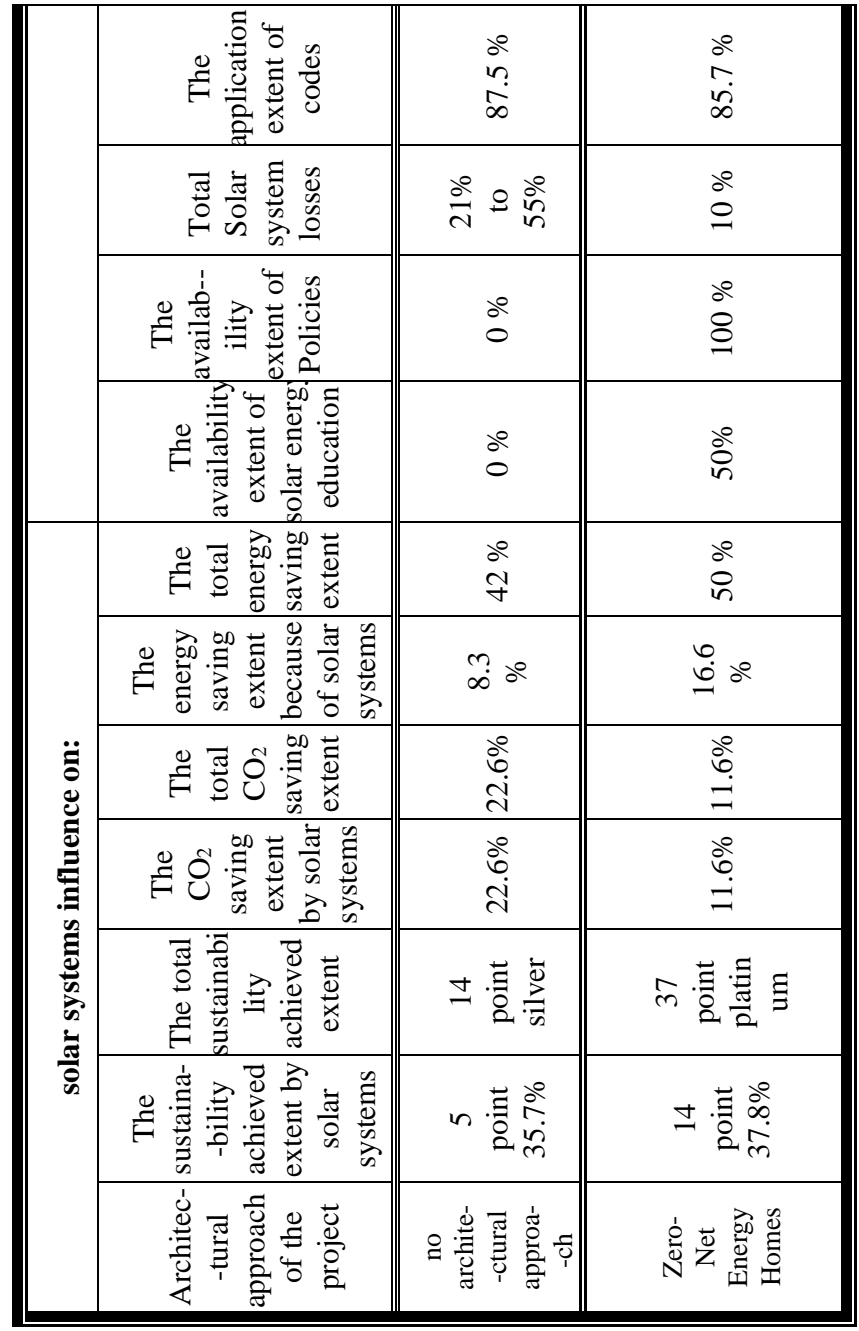

system in EX 8 for an existing building, the experience more successful. This indicates the possibility of adding solar systems for existing residential buildings.

Therefore, the lack of a clear strategy that enhance the use of SE systems affect negatively on success and spread of solar systems in residential buildings in Egypt.

\section{STRATEGY TO ENHANCE THE USE OF SE SYSTEMS IN THE EGYPTIAN RESIDENTIAL SECTOR}

Accordingly and from the previous analytical study, SE systems strategy should include four basic components: policies and programs, solar education, financial instrument, and legislations and building codes.

\subsection{Policies and Programs That Encouraging The Exploitation of SE in The Egyptian Residential Buildings}

Incentive policies such as the following: 
- Electricity tariffs includes environmental costs.

- Incentives on the solar system costs such as California utility loan program. This incentive provides $100 \%$ financing with $8.5 \%$ loan terms and repayment up to 10 years.

- Incentives on the solar system when connecting to the utility grid such as California Feed-In Tariff. This incentive sets a price for any excess electricity solar systems owners generate.

- Grants incentives to encourage and help poor and rural areas to own solar systems.

- Grants incentives to encourage the owning of BIPV.

Programs such as the following:

- Put a program to applying SWH in residential sector in Egypt through annual replacement for electric water heaters.

- if one square meter for each residential building (9.5 million single family and multiple families' type building in Egypt [37]), a great amount of energy consumption can be saved in residential buildings and carbon emissions can be reduced.

- Put a program to encourage SE local manufacturing through an institutional organizing. Local manufacturing of SE should provide spare parts markets, maintenance centers and representatives near the consumers.

- Put a Leasing program to provide solar consumers with solar systems from the government or utilities. Customer pays only system's installation and maintenance cost but the solar system is owned by the government or utilities.

- Transfer the ownership of the residential buildings roof to the administrative unit to put solar systems or requiring property owners to put solar systems as an essential condition to license any residential building.

\subsection{Solar Education That Encouraging The Exploitation of SE in The Egyptian Residential Buildings}

Provide information and knowledge by Set-up demonstration solar systems in public places, hold educational tours in this public places, provide printed materials (such as leaflets, brochures) containing information on solar systems, and increase awareness among politicians and senior officials.

Provide training by provide training course in Egyptian universities, Clever marketing for training programs through TV and newspapers, and organize small training businesses in poor and rural areas about manufacturing, marketing, installation and maintenance of SE equipment.

Provide public awareness by $\mathrm{TV}$, newspapers, and seminars in schools and universities.

Provide internet websites Create Egyptian internet sites for delivering good quality education and training for SE.

\subsection{Financial Instrument to Support SE in The Egyptian Residential Buildings}

For a proactive RE plan, the finance should be based on Egyptian funding and long term loans. Local financing can be supported through:

- The liberation of fuel prices will reduce the subsidy level. This subsidy can directed to finance RET systems.

- Imposing a carbon tax on power generated by traditional sources.

- There is an Alternative Energy fund created in the early 80s to finance nuclear power station and RET [36]. This fund should be reactivated to assist the private sector to invest in RET.

\subsection{Legislations and Building Codes That Organize The Use of SE in The Egyptian Residential Buildings}

The harmonization link should be completed between legislations \& building codes, and the solar technologies to assure that sustainable development practices deeply embedded at all levels of the design review and approval process. So that current legislations and building codes should be revised to include the following practices.

\subsubsection{Practices to activate the role of energy codes to achieve sustainability in residential buildings}

There are three areas of activity that relate to energy codes and their role in setting an effective baseline for Energy Efficiency (EE) and SE:

- Technical requirements: It means setting the minimum allowable level of efficiency for all buildings taking into account regular updates, regular interaction between the building code department and the building industry, whole-building scope, responsive to climate conditions, and increase code uniformity across country [41].

- Enforcement policies and practices: by Mandate code enforcement and penalties for lack of compliance[41].

- Code implementation and support: by code training and certification.

\subsubsection{Energy rating in building codes}

The government should require home energy ratings and EE retrofits at point of sale, remodel, or refinancing through activating the Green Pyramid Rating System and make it mandatory in buildings cods. This strategy makes the optimal use of SE in Egyptian residential buildings stock because every dollar saved through energy efficiency saves three dollars in a solar system.

Also Determine the maximum allowable load when license the residential building. This will stimulate those who made it to follow the design methods that take into account the energy conservation and energy production by solar. 


\subsubsection{Legislations to organize the sunlight access to the site and neighboring sites}

These legislations should be modified so that the relationship between distance among the buildings and the buildings heights allow the access of sunlight to all unites for one houre minimum for optimal use of SE.

From figure 50 and figures 51 , by modifying the law in Egypt to make the building height not exceed the scope of solar envelope. So the building height shouldn't exceed 0.75 width of the road. By this modifying the building south elevation has sunlight access and also west and east elevations have sunlight access for one hour a day.

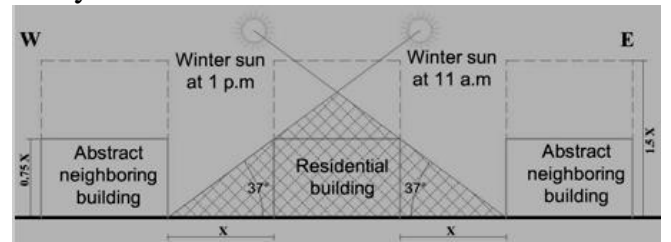

Figure 50 : west and east solar envelope in residential building in Egypt [researcher].

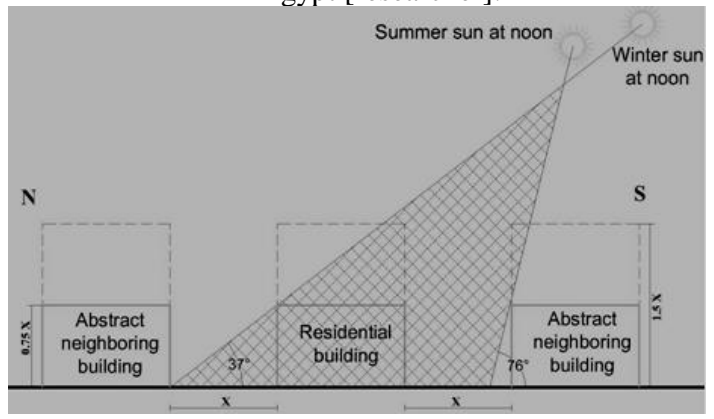

Figure 51: modified north and south solar envelope in residential building in Egypt [researcher].

\subsubsection{Codes legislations to warranty the solar} rights of the residential building user

local Egyptian governments have to be prohibited from creating barriers or using aesthetic considerations or unreasonable health and safety issues to prevent solar power system installations. So that Civil Code, Health \& Safety Code and Government Code should have terms prohibit these barriers as in California Codes.

\subsubsection{Putting solar systems conditions to comply with in residential building codes}

Solar-friendly building codes should be enacted in Egypt to include quality control, assurance components, installation requirements and equipment quality installation and maintenance for solar systems. This code will eliminate barriers to installing solar systems in residential building and fast-track the permitting process for buildings that integrate solar. So this code should have solar systems conditions to comply and items guarantee the quality of aspects affecting on the performance and design of solar systems.

\subsubsection{Legislations for building new homes that are solar renewable ready}

Perhaps the current time isn't suitable for the high prevalence of SE technologies, but it is a good time for residential buildings to be ready to use these technologies in the near future to save time, effort, and money by this easy way.

Ready buildings can be done by maximize the energy efficiency first because the smaller your energy needs, the less you'll need to spend on a SE system. Secondly, making siting and orientation decisions that will maximize the home's access to SE. Finally, installing electrical conduit and/or insulated copper piping during construction to avoid significant retrofitting costs by the following steps:

- Add brackets on the roof for mounting solar collectors or collectors can be fully integrated into the building structure itself.

- Insert large diameter multiple conduits for carrying the power or water piping from the roof, down through the walls and into the solar equipment room. This room houses the pumps for solar heat and/or inverters for PV to be added to the house circuits [15].

- Identify a path and install:

- For PV: $1.25 \mathrm{~cm}$ conduit near the utility panel through a building cavity and extend it into the designated attic to a point above the finished insulation depth. Clearly label the conduit for easy identification at a later date and air seal the top and bottom of the building cavity [42].

- For SWH: two $1.9 \mathrm{~cm}$ to $2.5 \mathrm{~cm}$ type $\mathrm{L}$ copper pipes from an accessible location in the mechanical room through a building cavity and extending into the designated roof to a point above the finished insulation depth. Pipes must be capped and insulated with $1.25 \mathrm{~cm}$ insulation the cavity air sealed at the top and bottom [42].

- Install a small access catwalk in the roof extending from the attic hatch to the location of the conduit to the estimated future location of the solar panels on the roof surface [42].

\section{CONCLUSION}

The paper has discussed the effectiveness role of SE in achieving sustainable architecture for residential building in Egypt and the approach to implement this role in Egypt.

The result obtained from the analysis of energy consumption in residential buildings and RE is the SE effective role to achieve sustainable architecture in residential buildings. So the paper has discussed SE, aspects affecting on the performance and design of SE systems, SE technologies options which appropriate to apply in residential buildings, Solar collectors mounting options which appropriate to apply in residential buildings, and change in the form and design of residential buildings which use solar energy technologies (A New Look of the Building). Also the paper has discussed solar policies, legislation and codes that encourage the exploitation of solar energy to achieve sustainability in residential buildings. 
In addition, The paper has analyzed practical residential experiences, which increase the contribution of SE in total energy mix. From this analysis, it can be concluded that SE is affected by building design, codes and legislation follow, and solar systems design factors follow; Also $\mathrm{SE}$ is influence on total energy saving extent, total $\mathrm{CO}_{2}$ saving extent, form \& design of the building, and sustainability achieved extent.

The result obtained from the analysis of RE situation in Egypt; SE technologies haven't reported a valuable level of required sophistication in Egypt because of lack of incentive policies from the government, lack of awareness, difficult situation of financial constraints, and absence of SE standards.

Through previous study, it can be concluded that the constraints of SE contribution in achieving sustainability should be overcome through follow a strategy to counter lack of incentive policies and programs, lack of awareness, lack of funding, and lack of legislation and laws. So the study but strategy to enhance the use of $\mathrm{SE}$ systems in the Egyptian residential sector. This strategy includes successful incentive policies and programs, diverse and comprehensive solar education methods, benefit from local funding, and legislation and building codes to assure that sustainable development practices deeply embedded at all levels of the design review and approval process.

This procedure could have application to other building types to achieve sustainability in Egypt. Also Attention must be paid to overcome contribution barriers of other design issues (Site- Materials- Wastes- WaterIndoor air quality) in achieving sustainability.

\section{REFERENCES}

[1] Szokolay,S.(2008). Introduction to Architectural Science The Basis of Sustainable Design. USA: Elsevier Ltd.

[2] U.S. Department of Energy.(2010). 2009 Renewable Energy Data Book. . Retrieved november 5,2010 from the world wide web : http://www.nrel.gov/learning/re_ basics.html.

[3] Hui,S.(2008). Building Environmental Assessment. Guest Lecture to HKU Department of Architecture [Arch 5305 Sustainable Building Systems]. Retrieved March 08 ,2010 from the world wide web : http://www3.hku.hk/mech/cmhui/ sbs/index.html .

[4] Basham, D.,\& Wright,J.,\& Ferguson,K.,\& Moy,G.(2004). Design: Solar Heating Of Buildings And Domestic Hot Water Approved(GPO NO. UFC 3-440-04N) . Retrieved March 08,2010 from the world wide web : www.wbdg.org/ccb/DOD/UFC/ufc_3_440_04n.pdf , UFC.

[5] Endecon Engineering.(2001). A Guide To Photovoltaic (PV) System Design And Installation. Retrieved March 01 ,2010 from the world wide web : http://www.energy.ca.gov/ reports/2001-09-04_50001-020.PDF:California Energy Commission.

[6] Wolter,N.(2006). Guide To Solar Electric Systems 2006. Retrieved January 02 ,2011 from the world wide web: http:// www.nrel.gov/docs/fy04osti/35297.pdf :Focus on Energy.
[7] Said , W.(2008). Solar energy refrigeration by liquid-solid Adsorption Technique. Master of science in clean energy and energy conservation engineering, An-Najah national University, faculty of graduate studies, nablus-palestine.

[8] National House-Building Council(NHBC).(2007). NHBC guide to renewable energy. Retrieved March 08,2010 from the world wide web : www.nhbc.co.uk/NHBCPublications /.../filedownload,30641,en.pdf . NHBC 2007.

[9] U.S. Department of Energy.(2008). Solar Swimming Pool Heaters. Retrieved March 02,2010 from the world wide web: http://www.energysavers.gov/your_home/water_ heating/ index.cfm/mytopic $=13230$

[10] Conserval Engineering, Inc.(2010). SolarWall® systems. . Retrieved March 02,2010 from the world wide web : http://solarwall.com/en/home.php.

[11] C.A.I. Technologies LLC. (2007). Hybrid-Solar Technology .Retrieved March 03,2010 from the world wide web: http://www.cai-tech.com/Sunlight/Technical.htm.

[12] Fayaz , M.(2009). Planning for Solar Energy as an Energy Option for Palestine. Master in Urban and Regional Planning, An-Najah national University, faculty of graduate studies, nablus-palestine.

[13] Home Power Inc.(2011). Solar Electricity Basics.home power magazine[on line serial]. Retrieved January 02,2011 from the world wide web : http://homepower.com /basics/solar/.

[14] Energy Saving Trust .(2005). Renewable energy sources for homes in urban environments(GPO NO. CE69). London : Energy Saving Trust.

[15] Galloway,T.(2004). Solar House: A Guide for the Solar Designer. Great Britain : Charon Tec Pvt. Ltd.

[16] Pro-Tech Energy Solutions, LLC.(2011). Solar Mounting Systems. Retrieved January 02,2011 from the world wide web : http://pro-techenergy.com/sp_implementing.cfm.

[17] Arizona Solar Energy Association \& the Arizona Solar Center Inc.(2010). Solar Application And Integration. Retrieved March 08,2010 from the world wide web : http://www.azsolarcenter.org/tech-science/solararchitecture/ solar-application-and-integration.html.

[18] Horizon Renewables Ltd. (2010). Solar Photovoltaics (PV).Retrieved March 03,2010 from the world wide web: http://horizonrenewables.co.uk/solar-photovoltaics/ photovoltaic-panels-roof-mounted.html

[19] National Renewable Energy Laboratory.(2009). A Consumer Guide to Solar Electricity for the Home. Retrieved March 01,2010 from the world wide web : http://www.nrel.gov/ learning/pdfs/43844.pdf: U.S. Department of Energy.

[20] Gevorkian,P.(2008). Solar Power In Building Design The Engineer's Complete Design Resource . USA: The McGraw-Hill Companies, Inc.

[21] Hui,S.(2007). Renewable Energy Systems. Building Energy Efficiency Research project, Department of Architecture, The University of Hong Kong, Hong Kong.Retrieved March 08,2010 from the world wide web : http://www3.hku.hk/mech/cmhui/sbs/index.html.

[22] Abdulaziz ,K. (2007). Smart homes »protect the environment and save energy.Retrieved March 02 ,2010 from the world wide web : http://www.beaah. com/home/Env-articles/envNews/2007/16-janecology-team.html.

[23] Architecture View Inc. (2011). Modern Ultra Efficient Home in Danish.Retrieved March 03,2010 from the world wide web: http://www.architecture- 
view.com/2010/09/27/modern-ultra-efficient-home-in-

danish/.

[24] Residental Energy Services Network (RESNET).(2011). What Is A Home Energy Rating?. Retrieved January 02 ,2011 from the world wide web : http://www.resnet.us/ home-energy-ratings

[25] Morello,E.\& Ratti,C.(2008). Sunscapes: 'solar envelopes' and the analysis of urban DEMs. Retrieved March 01,2010 from the world wide web : http://senseable.mit. edu/papers/pdf/2008_Morello_Ratti_Journal\%20of\%20Co mputers\%20and\%20the $\% 20$ Environment.pdf.

[26] California Department Of Forestry And Fire Protection Office Of The State Fire Marshal. (2008). Solar Photovoltaic Installation Guideline.Retrieved March 03 ,2010 from the world wide web: http://osfm.fire.ca.gov/pdf/reports/

solarphotovoltaicguideline.pdf.

[27] Scottsdale green building program. (2010). Residential Solar Plan Review Quality Submittal Guidelines. Retrieved March 01,2010 from the world wide web : http://fliiby.com /file/772252/u7ct3scgvm.html.

[28] Department of Design, Construction and Land Use, City of Seattle.(2002). Solar Electric Systems for Homes in Single Family Zones.Retrieved March 03,2010 from the world wide web: http://www.seattle.gov/DPD/Publications/cam420.pdf.

[29] California Public Utilities Commission . (2009). 2008 building energy efficiency standards residential compliance manual (GOP NO. CEC-400-2008-016-CMF-REV-1). California , DC: California Energy Commission Arnold Schwarzenegger Governor.

[30] Energy Center of Wisconsin.(2001). WisconSUN Case Study: The Bircher Home. Retrieved April 09,2011 from the world wide web : http://www.ecw.org/wisconsun/learn/cs_bircher.shtml

[31] Wakeland Housing \& Development Corporation.(2011). LosVecinos. Retrieved April 09,2011 from the world wide web: http://www.wakelandhdc.com/projects /los-vecinos

[32] VRBO, Inc..(2011). Heavenly Retreat - Your Private Solar Home in the Rockies. Retrieved April 09,2011 from the world wide web: http://www.vrbo.com/324955
[33] Galloway,T.(2004). Solar House: A Guide for the Solar Designer. Great Britain : Charon Tec Pvt. Ltd.

[34] Solaripedia,Inc.(2010). Florida Solar Cracker House. Retrieved April 09,2011 from the world wide web : http://www.solaripedia.com/13/59/519/florida_solar_cracke r_house_exterior.html

[35] Conserval Engineering, Inc.(2011). SolarWall PV/T: AIM Associates. Retrieved March 02,2010 from the world wide web : http://solarwall.com/media/download_gallery/cases/ AIMAssociates_Y02_SolarWallPVTCaseStudy.pdf

[36] Abu State,N. (2007). Study: Egypt expectations of a shift to an importer Of oil by the year 2017 due to population increase Steady. Retrieved February 10,2010 from the world wide web : http://archsustainable.blogspot.com/2007/02/blog-post_10.html

[37] Industrial Modernization Center, Renewable Energy Sector in Egypt (December ,2006). Tender: (IMC/PS_217) Final Report . Retrieved november 5,2010 from the world wide web : http://www. imc-egypt.org/ar/ListofStudies.asp

[38] Earthtrends .(2005). Energy and Resources-- Egypt. Retrieved november 5,2010 from the world wide web : http://earthtrends.wri.org/select_action.php?theme $=6$

[39] NREA. (2010). Annual Report 2009-2010. Retrieved March 03,2010 from the world wide web : http://www.nrea.gov.eg/annual\% 20report/annual 2010.pdf.

[40] The Housing and Building National Research Center.(2011). The Green Pyramid Rating System (GPRS). Cairo,Egypt: The Housing and Building National Research Center.

[41] The Building Codes Assistance Project of the Alliance to Save Energy.(2009). Building Energy Codes : Best Practices Report for APEC Economies. Retrieved March 08 ,2010 from the world wide web : http://www.scribd.com/doc/ 27113942/Building-EnergyCodes-Best-Practices-Report-For , U.S. Department of Energy ,\& U.S. Environmental Protection Agency.

[42] Focus on Energy.(2007). Building New Homes That Are Renewable Ready. Retrieved March 01 ,2010 from the world wide web http://www.focusonenergy.com/files/document management_system/residential_programs/buildingnewho mesrenewableready_factsheet.pdf 